\title{
ANZTLA SA Chapter Report 2016 Hayley Eyers
}

\section{South Australian Members of ANZTLA 2016:}

Adelaide College of Ministries Library, Adelaide College of Ministries Adelaide Theological Library, Adelaide College of Divinity Australian House of Prayer for All Nations Library, Australian House of Prayer for All Nations

Burrow Library, Bible College of South Australia

Catholic Resource and Information Service, Catholic Education South Australia Löhe Memorial Library, Australian Lutheran College St Barnabas Library, St Barnabas Theological College Tabor Library, Tabor College of Higher Education

\section{News from the ANZTLA SA Chapter:}

Due to the common experience of budget cuts for several of our libraries, we have had discussions regarding the possibility of purchasing and/or sharing common resources. As each library has different sources of funding, it is perhaps more practical to consider reciprocal borrowing and interlibrary loans without fees across all our libraries. To date, no agreement has been formalized, as there are pros and cons such as librarians being required to pick up and return resources, and lending libraries being left short of resources for their own students. There has also been a suggestion to investigate at least one library having a continued run of common periodical titles. There may be licensing issues with this idea.

Wendy Davis retired as ANZTLA Archivist at the end of 2016 and the ANZTLA Archives are to be rehoused due to the refurbishment of the Adelaide Theological Library at Brooklyn Park campus. 
Katrina Dal Lago from Tabor Library will be the new ANZTLA Archivist. Barbara Cooper at Burrow Library will house the ANZTLA Archives in her library from early in 2017.

Adelaide Theological Library can no longer accept donations after Friday 16th December due to the pending refurbishment/redevelopment of the campus in 2017/2018 This will involve moving and downsizing the present library collection. The following is a list of libraries that currently are still able to accept donations of theological material:

Presently the Lutheran College Library (Löhe Memorial) will accept books as will the Oxfam Bookshop on Hutt Street.

St Barnabas College Library is happy to take anything of an Anglican nature, written by or about Anglicans and also on Anglican Church History in Australia.

Wendy Davis retired from Adelaide Theological Library on 16th December 2016. Hayley and Rosemary are sad to see her go and will miss her experience, knowledge, skills and personal contributions to the ATL team since she began with the combined library in 1997. Wendy has been part of the theological library scene in Adelaide since 1981 when she began work at Lohe Memorial Library, Australian Lutheran College. She has worked with Adelaide College of Divinity Libraries since 1984-firstly at St. Barnabas College and from 1993, at St Francis Xavier Seminary Library as well. In October 1997, she became Associate Librarian at the new Adelaide Theological Library. Wendy is a long time ANZTLA member, past President, past Secretary (for two terms), current Archivist, Chair of the organising committee for the 2013 Adelaide Conference, and ARI indexer. When Val Canty was ANZTLA newsletter editor, Wendy was her unofficial assistant and proof reader. Wendy was awarded an Honorary Life Membership in 2015 for her extensive contributions to ANZTLA over many years. We wish Wendy and her husband, Mark, every blessing and happiness in their retirement, which promises to be very busy with travel and spending time with their two grandsons. Barbara Cooper presented Wendy with a bunch of flowers and a certificate of appreciation at the ANZTLA SA meeting in November 2016. 


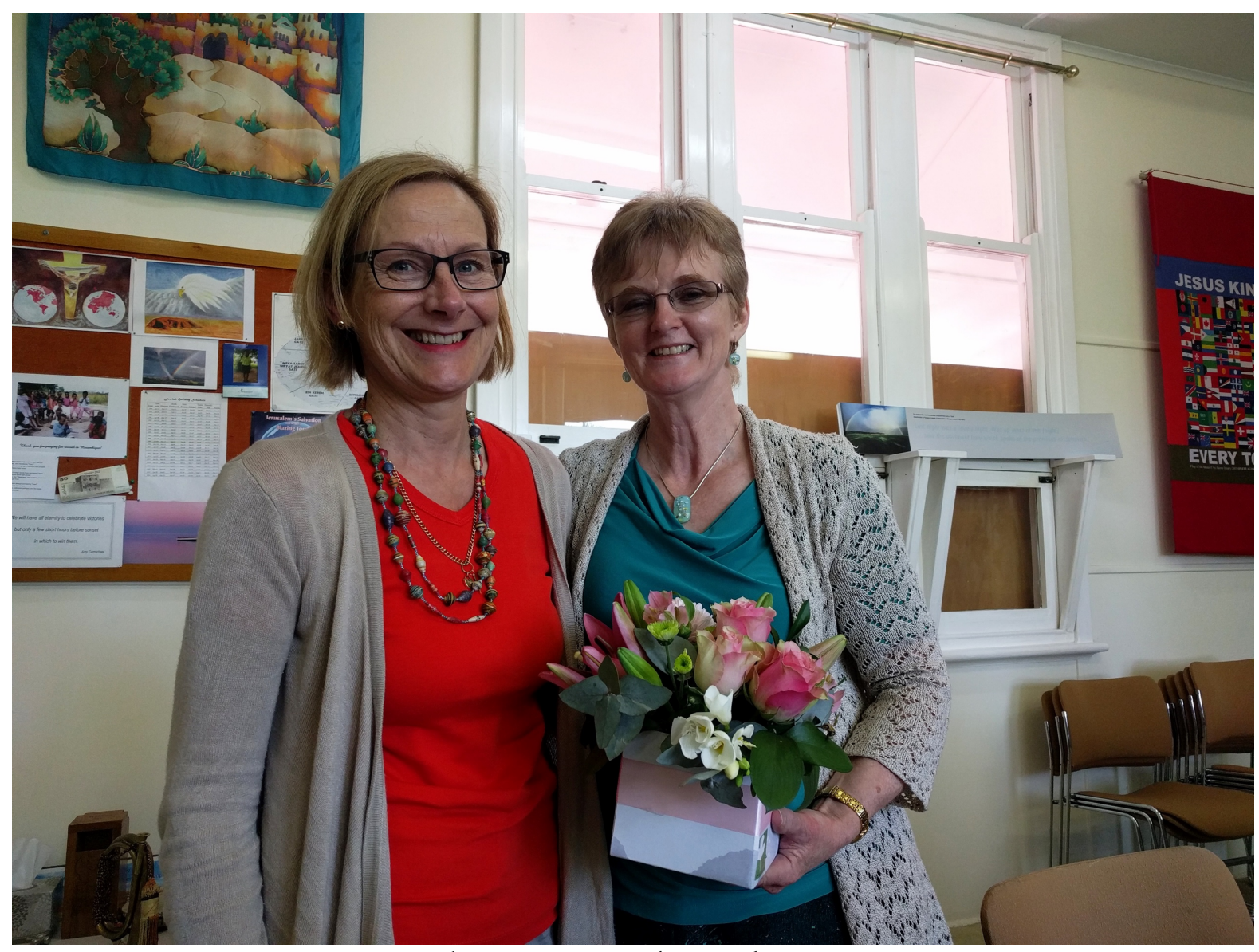

Barbara Cooper with Wendy Davis

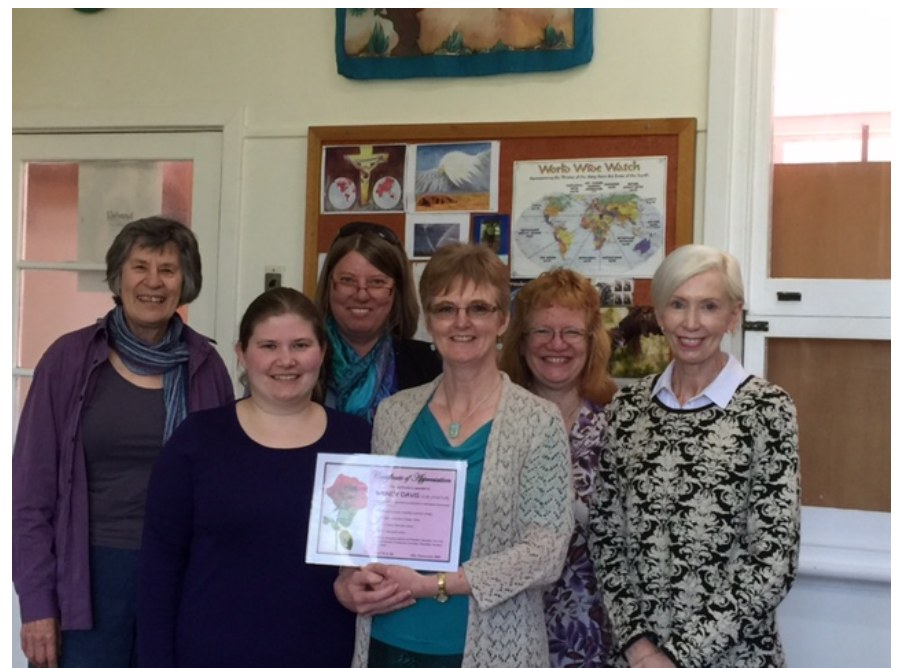

SA Chapter members with Wendy Davis

\section{ANZTLA Conference Canberra:}

Hayley Eyers (Adelaide Theological Library), Helen Gorzkowski (Tabor Library), Rosemary Hocking (Adelaide Theological Library) and Trevor Schaefer (Löhe Memorial Library) attended the ANZTLA Conference 29 June - 2 July in Canberra. 
Trevor Schaefer did a lighting talk presentation titled '1551 Lutheran Bible: Wood cut illustrations illuminated'.

\section{Library Reports}

\section{Adelaide College of Ministries Library}

Adelaide College of Ministries is closing at the end of the year. As part of early discussions between ACM and Bible College SA, BCSA will be welcoming to our ongoing students and some faculty.

Decisions are unlikely to be made before sometime during the next year. In the meantime, we will be closing our membership with ANZTLA and winding up any other subscriptions. Thank you so much for your advice and support since I started engaging with ANZTLA in 2011. Your encouragement has been invaluable as our tiny College has aimed to keep up with the big guns in this field. It is a sad time for us all, but I am grateful for ANZTLA broadly and for the SA Branch. Your encouragement at conferences and through this forum has been invaluable as our College has aimed to keep up with larger institutions in this field.

\section{Tamara Wenham}

\section{Adelaide Theological Library}

The ACD has updated their website, and continues to host the Library page. Wendy took this opportunity to update many embedded links as the URLs all changed and improve our web page information. The ATL now has a Facebook page, which includes forthcoming events, library news, and items of general interest.

The Uniting Church (SA) is now the owner of the ACD campus. Plans are being developed to "refurbish" the site, which will involve moving the ATL as well as all other parts of the existing campus to re-developed buildings with a smaller total footprint, but on the same site. Library staff and volunteers were invited to a meeting at which the first draft concept plans for the re-development of the campus were presented. The current plans do not allow sufficient space for the existing library collections, so we are already investigating options eg. compactus storage for older materials, and whether we will have space to house our rare books collection. Library staff have continued to meet with the architects to refine plans for library space in the 
refurbished ACD campus. We will need to reduce our catalogued collection by $25 \%$, so we have started weeding duplicates of non-core texts from the main collection, and will be disposing of all uncatalogued items in the stacks collection. We will no longer have space to store the rare books collection.

We have noticed a significant reduction in the number of student visits, borrowing totals, and photocopier use. A major contributor to this is be the increased use of the Moodle-based learning software, ACD Online, to support the topics being taught; and we are promoting the use of our electronic journals, research databases and ebooks, which are particularly useful for our distance students.

We were very pleased with the response to the display of artworks by Yvonne Ashby, the ACD Artist-in-Residence. And Yvonne's mural has definitely brightened up the library entrance. We hosted a Living Libraries lunchtime presentations for South Pacific School Aid and Kairos Prison Ministry during the year.

Wendy retired as of $16^{\text {th }}$ December. We will be very sad to see her go, and will miss her experience, knowledge, skills and personal contributions to the ATL team since she began with the combined library in 1997.

\section{Rosemary Hocking}

\section{Australian House of Prayer For All Nations}

Continuing to put aside books tapes etc. to send to a contact in PNG. Until the end of the year I will be down one volunteer who is going to the UK with her husband till the end of December. She is my right hand 'man' so to speak looking after the journals/newsletters of which we have many. She tried to bring the holdings on 'AULOTS' up to date but ran out of time before she had to fly out. The other volunteers are learning new skills and will be able to cover her position ably, but we will still miss her.

We are still waiting for new premises to house everything on one (much bigger) site. We are about to send one or two pallets to PNG of books, audio tapes and videotapes. A volunteer from Adelaide has moved to Kingscote, Kangaroo Island and has begun spending time in the House of Prayer Library room over there in the Kingsgate Haven Motel. Currently we have sent 128 items to that site.

\section{Pauline Redman}




\section{Burrow Library}

The cataloguing of resources donated by the Evangelical Library has commenced and will probably take several months to complete. Accession of these books also requires some reconfiguring of shelf space.

Our college newsletter has brought two new volunteers to the library, who have been able to sort through donations and who, I hope, may be able to learn simple cataloguing in time.

A current project is to review and essentially rewrite our library policy documents as they are very out-of-date. The Australian College of Theology Library Policy document suggests guidelines and standards, which are forming the basis of this work. The ACT Annual Survey requires library performance metrics, which in turn need a mission statement/strategic plan as well as collection development policy. I have been creating and updating some of the library policy documents as part of our performance metrics process. This has been a useful review of the way the library runs and hopefully will help determine planning and direction for next year and beyond.

We have a new library volunteer who comes generally once a week with her aunt, who supervises her, and she is gradually learning how to work within our Liberty catalogue.

A student survey has been performed, which has gathered useful feedback regarding the performance of the library in meeting their needs. Some trends in responses have emerged that will hopefully be addressed with orientation of students as the new academic year commences. The main issue is to ensure that all students receive the information they need. I am thinking of compiling a checklist that students need to sign to confirm they have eg. been shown around the library; know how to access online journals; Endnote, etc.

We are in the process of seeking a library assistant who is familiar with Liberty and can help with the cataloguing of donated books. This is a paid position for 4 hours per week. We have had a new volunteer who has been able to help sort through donated books and also enter contents into our catalogue. 
A stock take is planned for the end of this semester.

Barbara Cooper

\section{Catholic Resource and Information Service}

A review of CRIS has been ongoing for almost 2 years and the report has now been finalised. At this stage we are waiting to see what recommendations the review has outlined.

Staffing has been cut to one full time librarian and now a half time library assistant. This has meant that the service is now closed to the public on Thursday afternoons and Fridays. Mary McCormack, the previous library assistant, retired as of April this year and has been replaced by Sarah Pietsch who works Monday afternoon, Tuesdays and Wednesdays. Sarah has previously worked in different departments at Catholic Education and has had experience in school libraries in Canada.

There is an increased demand on CRIS service from schools and parishes but difficulty with supplying the same service with less staff and a decrease in budget.

We were fortunate to have a $4^{\text {th }}$ Year TAFE Library Studies student, Vicky Hammond, to complete a placement with us of 70 hours volunteer work.

Susan Newland 


\section{Löhe Memorial Library}

The Acquisitions and Liaison Librarian, Pam Zweck Silcock retired at the end of January 2017. The recruitment process for a replacement went ahead before the end of 2016. A new librarian was appointed, Sara Altmann, and she commenced in January 2017.

In July, two library staff members attended conferences. Trevor attended the annual ANZTLA Conference in Canberra, and Pam attended the Luther Conference in Melbourne. The Löhe Library and ALC were promoted at both conferences, through the showcasing of the recently compiled "Luther Bible 1551", a compilation of selected illustrations from the original Bible, with theological commentary to each illustration.

The Senior Librarian attended a UD Library and Academic Resources Committee (LARC) meeting in Melbourne. The main issues of note were:

- Plans to develop a common user card for all UD library members, across the network of libraries. This dovetails well with our own plans in this area.

- Guidelines for deselection across the libraries. It was agreed that while there are principles that apply to all of the libraries in general, there will be local circumstances which need to be taken into account.

- Plans to develop a working party to review items added to the UD Hub, in consultation with faculty, so that digital collections closely align with the needs of the University teaching programme.

The Senior Librarian met with the Senior Teaching Staff in August to review resources added to the catalogue by department. It was agreed that there will be regular faculty reviews of collections in relation to teaching needs, and a review by department heads was conducted in December.

The library staff have rationalised the print collections, and relocated seldom used books, mostly in old German script (approximately 4000 items), to areas of the shed vacated by uncatalogued and unused serials. This has enabled significant weeding in the main collection, and removed the double shelving in the compactus. 
The Senior Librarian worked with the Web Administrator and ICT to effect some improvements to the web infrastructure. This has resulted in the establishment of a secure landing page for ALC held digital resources, requiring a single login, instead of the multiple types of logins as was the case previously. The UD Hub continues to be the first stop for students searching for online resources.

The Library Management System is currently running on a Server 2003 using Internet Information Services (IIS) version 6, neither of which are still supported by Microsoft. Sirsi Dynix, the library system software provider, have informed us that the next upgrade of the sof tware is imminent, and will be unable to run on our current server environment. The LMS will be migrated to Server 2012, and a cloud (SAAS) hosted option in April/May 2017.

Shaun M. Lancaster

\section{St Barnabas Library}

We have made good progress in the library despite the time pressure. I have a good team of volunteers. 4 men who are work on average about 5 hours each per week unpacking and sorting books from the boxes and Fiona, a retired librarian who comes each Wednesday and catalogues for me.

As of January 12017 I will be Tuesday - Friday, Library Manager (paid) and no more Academic Administrator. This is a fully funded position and after nearly 2 years of the split role I am very glad that it's coming to an end. Damian Szepessy has been appointed Academic Administrator 3 days per week and Ros is in the middle of training with him.

In September, the College re-branded itself and is now St Barnabas College, no apostrophe and no 'theological' in the name. Colours etc. have all changed and there is a new look website etc. There is work to be done on the introductory library page as it was put together by someone else and needs attention!

There is a good team of volunteers coming together and the main aim of 2017 is to catalogue and catalogue and catalogue! There is much 'second and third level sorting' to be done with my main task over the summer to write up, more fully, a Collection Development Policy. 
We currently have just over 2,000 books in the catalogue with a goal of 15,000 by the end of 2017. We also hope to commence lending (St Barnabas students and staff only to begin with) by the middle of 2017.

One of the good things for me about 2017 will be the fact that attending ANZTLA meetings will become a whole lot easier and I look forward to the shared time together.

Rosslyn (Ros) Devenish

\section{Tabor Library}

Library staff have undertaken another weeding project. The aim is to create more study spaces for students, in particular quiet study space. We have done this by deleting duplicate copies, old editions of text books, moving a lot of books to stacks.

Oksana attended the OCLC Libraries at the Crossroads Conference in Hong Kong. The conference was held on the 1-2 December and a Lightning Talk video submitted by Oksana was shortlisted and screened at the Conference. The theme of the video had to relate to young people and how your library kept them engaged in terms of technology, changing the library space or how they are encouraged to come into your library either physically or virtually.

Tabor College looking at opportunities to form alliances with other colleges. Currently, Tabor College in Adelaide has combined with Tabor College Perth, so that Tabor College Perth falls under the banner of Tabor College. There are also Teaching Centres in Geelong and Midland (WA) that are now part of Tabor. The library in Perth (Forrestville) will remain open and there is a part-time staff member in the library. Since the amalgamation, we have been busy changing some of our policies and procedures as they are no longer appropriate now that we also have interstate campuses.

\section{Oksana Feklistova}

